\title{
Understanding People
}


Also by Trevor Butt

Invitation to Personal Construct Psychology (with Vivien Burr) 1992 


\section{Understanding People}

TREVOR BUTT 


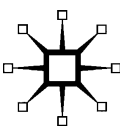

(C) Trevor Butt 2004

All rights reserved. No reproduction, copy or transmission of this publication may be made without written permission.

No paragraph of this publication may be reproduced, copied or transmitted save with written permission or in accordance with the provisions of the Copyright, Designs and Patents Act 1988, or under the terms of any licence permitting limited copying issued by the Copyright Licensing Agency, 90 Tottenham Court Road, London W1T 4LP.

Any person who does any unauthorised act in relation to this publication may be liable to criminal prosecution and civil claims for damages.

The author has asserted his right to be identified as the author of this work in accordance with the Copyright, Designs and Patents Act 1988.

First published 2004 by

PALGRAVE MACMILLAN

Houndmills, Basingstoke, Hampshire RG21 6XS and

175 Fifth Avenue, New York, N.Y. 10010

Companies and representatives throughout the world

PALGRAVE MACMILLAN is the global academic imprint of the Palgrave Macmillan division of St. Martin's Press, LLC and of Palgrave Macmillan Ltd. Macmillan ${ }^{\circledR}$ is a registered trademark in the United States, United Kingdom and other countries. Palgrave is a registered trademark in the European Union and other countries.

ISBN 978-1-4039-0465-2 hardback

ISBN 978-1-4039-0466-9 ISBN 978-0-230-00059-9 (eBook)

DOI 10.1007/978-0-230-00059-9

This book is printed on paper suitable for recycling and made from fully managed and sustained forest sources.

A catalogue record for this book is available from the British Library.

A catalog record for this book is available from the Library of Congress.

$$
\begin{array}{rrrrrrrrrr}
10 & 9 & 8 & 7 & 6 & 5 & 4 & 3 & 2 & 1 \\
13 & 12 & 11 & 10 & 09 & 08 & 07 & 06 & 05 & 04
\end{array}
$$

Typeset in Great Britain by Aarontype Limited, Easton, Bristol 


\section{Contents}

Preface

vii

Part I From Personality to Sogial Psychology

1 The Dimensions of Personality 3

Issues in personality 4

Personality: a modern concept 12

$\begin{array}{ll}\text { Understanding people } & 17\end{array}$

2 Personality Theories 1: Trait, Biological and Cognitive

Social Approaches $\quad 21$

Trait and biological approaches $\quad 22$

$\begin{array}{ll}\text { Cognitive social approaches } & 29\end{array}$

The person in cognitive social theories 33

3 Personality Theories 2: Psychoanalytic and

Humanistic Approaches $\quad 40$

$\begin{array}{ll}\text { Psychoanalysis } & 41\end{array}$

Humanistic approaches $\quad 48$

$\begin{array}{ll}\text { The person in psychoanalysis and humanism } & 57\end{array}$

4 The Social Constructionist Critique of Personality 60

$\begin{array}{ll}\text { Social constructionism } & 61\end{array}$

$\begin{array}{ll}\text { The person in social constructionism } & 69\end{array}$

$\begin{array}{ll}\text { The social construction of reality } & 73\end{array}$

$\begin{array}{ll}\text { The roots of constructionism } & 77\end{array}$

Part II An Existential Phenomenological Approach

5 Interpretive Understanding 83

Verstehen and hermeneutics $\quad 84$

Phenomenology 88

Mead's social psychology 100

$\begin{array}{ll}\text { A synthesis } & 103\end{array}$ 
6 The Causes of Behaviour 108

$\begin{array}{ll}\text { The influence of the past } & 109\end{array}$

The effects of the situation 115

7 The Sense of Self 125

$\begin{array}{ll}\text { The self in late modernity } & 126\end{array}$

$\begin{array}{ll}\text { The existential self } & 129\end{array}$

Fragmentation and the sense of self $\quad 132$

$\begin{array}{ll}\text { Personal agency } & 136\end{array}$

8 The Unconscious 140

The dynamic unconscious $\quad 141$

$\begin{array}{ll}\text { The existential project } & 149\end{array}$

9 Psychological Reconstruction 159

$\begin{array}{ll}\text { The rise of therapy } & 161\end{array}$

Emotions and feelings $\quad 163$

Social and personal construction 166

The point of understanding $\quad 174$

$\begin{array}{ll}\text { References } & 178\end{array}$

Author Index 186

$\begin{array}{ll}\text { Subject Index } & 189\end{array}$ 


\section{Preface}

Understanding People seems at first glance a rather pretentious title for a book. When my friends in the clinical world have asked me what the title was to be, a common reaction has been something like 'well, if I give you a couple of names, perhaps you'll let me know what makes them tick'. So first of all, I should say what I mean by understanding. I have spent most of my professional life involved in personal construct theory (PCT) and naturally think in terms of dichotomous constructs. To know what something means you have to see what its contrast is. Understanding versus explaining is a construct that Dilthey (1988) used in the nineteenth century, arguing that the social sciences should not be concerned with causal explanations. Instead they should concentrate on understanding people in the same way that one understands a text. When we read something, we get an appreciation of what it means by moving between part and whole, looking at a word and seeing how it fits into a sentence. So, for example, we only know what 'train' means when we see that it is used as a verb rather than a noun. Similarly, the meaning of a sentence only becomes clear when we can place it in a larger context. When someone says of a partner, 'Yes, I've got him well-trained', we know that the meaning is somewhat ironic. At the same time, the meaning of the whole relies on the parts and a sentence only has meaning by virtue of the words that constitute it. But psychology is the social science most enamoured with the natural sciences and has usually sought meaning by looking for causal explanations at a more molecular level. The psychology of personality has largely been a project engaged in trying to find the causes of individuals' behaviour, either inside them or in the environment.

Now, causal explanations might have a place in psychology, and one could argue that the explanation versus understanding construct is too crude to capture what personality theorists have been up to. So perhaps explanation is a particular type of understanding and not a simple contrast to it. Nonetheless, I maintain that it is a useful distinction, one that draws our attention to what is frequently missing in 
the science of personality - an understanding that does not rely solely on an ability to tell us what kick-starts the person into action. In my view, understanding people requires two things: their account of their reasons and how the world appears to them as well as an appreciation of the social context in which they are embedded. By moving our focus from one to the other and back again, we can begin to make sense of what people do, feel and think. This corresponds roughly to what Ricoeur (1970) describes as a 'hermeneutics of belief' or empathy and a 'hermeneutics of suspicion'. An interpretation based on empathy has to be balanced with one that takes into account things that the person might not, or even cannot, know. The psychologist has to start with how things appear to people, but must not stop there. It may be that unconscious forces or the discursive field within which one moves are not apparent to actors themselves. People might not be in a position to know exactly why they think, feel and act as they do. Interestingly, while personality theorists have been largely looking 'inside' people for answers, a very different approach to the person has been evolving in social psychology. Social constructionism (Burr, 1995) can be thought of as a family of approaches that emphasise the role of social forces, particularly language, in the production of individual action. Kenneth Gergen (2001), the originator of this approach, has made some bold moves towards transcending the agency versus structure issue. This is the debate about whether human action is the product of the individual agent or social forces that determine them (see Walsh, 1998). Determinism might play no part in Gergen's thinking but my contention is that, in the UK at least, variants of social constructionism represent a pendulum swing away from individual agency and towards an overestimation of the forces of social structure. Causal explanations beckon not from within the person, but from ideologies and discourse that move people in ways of which they are not aware.

So how are we to conceptualise the person? My answer to this question is based on a mixture of the pragmatism of both George Kelly and George Mead and the existential phenomenology of Maurice Merleau-Ponty. Interestingly, Berger and Luckmann (1967), on whose work social constructionism has built, drew on both pragmatism and existential phenomenology. Their work conceptualised the individual as a social construction, but nevertheless a centre for agency and choice once constructed. For contemporary social constructionism, it is therefore flawed in that it preserves a mythical sense of personal agency. But I want to return to this conception and 
elaborate the interpretive, interactionist, agentic constructionism that is inherent and sometimes explicit in pragmatism and existential phenomenology. As you read this last sentence, you might think I've swallowed a psychological dictionary. And this has been my main problem in writing: what do I call the position that I am advocating? I could make up yet another new term or phrase, but I think that both social psychology and personality theory are already overfull with old wine in new bottles. So I have decided to stick to an older vocabulary - that of existential phenomenology. I have chosen this because it seems to me to be an overarching theoretical position that can subsume the pragmatism of Kelly (1955) and Mead (1934), both of whose work considerably extends existentialist thinking. I see myself still as a construct theorist, but my view of PCT is not orthodox or accepted uncritically within the PCT world. I see it as a species of existential phenomenology, albeit one that does not use the somewhat mystifying vocabulary of this approach (see Holland, 1977; Butt, 1998). Pragmatism was an American philosophical movement that developed in parallel with existentialism and phenomenology in Europe. (Interested students should read Menand's (2002) fascinating and compulsively readable history of pragmatism.) In many ways the two approaches complement each other, although their emphases are often different (Rosenthal and Bourgeois, 1991). So in this book, I have chosen to sail under the flag of existential phenomenology, sometimes mentioning pragmatism and interactionism as signposts to help the reader. One cost of this strategy is that I do use that terminology that Keen (1975) says English speakers find odd and even irritating. Phrases like 'being-in-theworld' have been translated directly from German, where the compound nouns have been rendered into somewhat clumsy English equivalents. But 'being-in-the-world' is a concept that I want to promote. The thesis of this book is that understanding people means recognising that we are both all alike and at the same time all different. Psychology has often ignored how we are all beings in the same world, a commonality of situation and culture that enables us to communicate with each other at all. And structural sociology has often forgotten that the way we experience the world is very different, and in this sense we are beings in different worlds. Such concepts are therefore central to this book, as we struggle to make sense of both ourselves and others.

Another problem with calling my position existential phenomenology is that most theorists in this field would dislike my bringing the 
work of Mead and Kelly under the existential phenomenological umbrella. The closer you get to theories and approaches, the more apparent are the differences between them. But I have chosen to emphasise the similarities between existential phenomenology and pragmatism. This is because, in my view, they share enough common ground that marks them out as different from other approaches to personality. So, they both stress the importance of individual perspectives and first-person accounts in understanding people. Yet both recognise the complex relationship between the person and the social world. In the other personality theories reviewed in subsequent chapters, there is an implicit assumption that the person precedes society. By this I mean that they view the person as a social atom and society as an amalgam of the individuals that make it up. They do not take seriously the proposition that society acts back on the individuals in it and, in an important sense, we are each the product of our society.

It will make most sense to read this work in the order that it is presented. I have tried to write it as a coherent story, taking the reader through from one chapter to the next. If you decide to read it differently, I have cross-referenced wherever possible, so that you can see in which chapters various points are elaborated. To avoid any clumsiness in the use of pronouns, I have used he and she in alternate chapters. In Part I, I briefly review different personality approaches. A theme that emerges is that traditional approaches to personality are rooted in two problematic dualisms: one that separates mind from body and one that separates the individual from society. This leads to an explanatory enterprise that seeks causes of behaviour. I then review social constructionism, arguing that it breaks the dualist mould in a helpful way, yet drifts into a psychology in which the person evaporates entirely. I have called Part I From Personality to Social Psychology to underline the importance of the social constructionist critique in the understanding of people. This externalising moment sets the scene for Part II. Here I outline the alternative that I am proposing, tracing its roots and then showing how the issues and puzzles of personality look very different from its perspective. Here I call on phenomenology not only as a theoretical base, but also as a method, trying to engage the reader in imaginative variations and thought experiments (Ihde, 1986) to argue my points. I conclude by contending that the science of personality is both a practical and moral enterprise. Not only is understanding necessary in helping people to change and accept themselves, but it is something to which 
we ought to aim. The psychology of personality has to give up trying to be clever and explain people's behaviour. Yes, its job is to have a practical impact, but also to develop a vocabulary for moral reflection. In a world where tolerance is in short supply, the social scientist should interpret and speak for the marginalised, the foreign and the distressed.

One problem in trying to review so many different approaches in such a short space is that there is an ever-present danger of making straw men out of the opposition. Having said that understanding involves seeing things from the other's point of view, I felt bound to canvass the views of proponents of other positions as well as those of my own. I therefore submitted drafts of chapters to and discussed the ideas with friends who are psychoanalysts, social constructionists and therapists of different types. So I am indebted to Phil Salmon, Vic Sedlak, Ken Gergen, Peter Ashworth, Annika Gilljam and Angela Douglas for their very helpful comments. I would also like to acknowledge the strong support I have received from my friends and colleagues in the Centre for Constructions and Identity at the University of Huddersfield. This comprises sociologists and psychologists, a mixture of people and approaches without whom I could never have developed the view I elaborate here - in particular, Darren Langdridge, who tirelessly read and commented on various chapters; but also Viv Burr, Graham Gibbs, Dallas Cliff, Rudy van Kemenade, Jeff Hearn, Donna Gornall and Gary Fry all in different ways offered support throughout the project. All my contacts at Palgrave Macmillan, Frances Arnold, Andrew McAleer, Magenta Lampson, and Maggie Lythgoe have been a source of strong encouragement, and my partner June has been patient and understanding as I became more obsessed and absorbed with this project. I'm very grateful to Geoff Adams, who came to my aid in offering to construct the index just when I was running out of steam. Finally, I would like to thank the School of Human and Health Sciences Research Committee at the University of Huddersfield that made the whole thing practical by giving me sabbatical leave.

I won't say this work has been easy. Time and again I have remembered the wisdom of the late Douglas Adams: 'I can tell anyone how to write. You just sit in front of your Mac until blood comes out of your forehead.' But it has been enjoyable and, in retrospect, this has made it seem easier than it was. Since psychologists are fond of quantification, I could end this preface by saying that if you enjoy reading this book just half as much as I have enjoyed writing it, then I've 
enjoyed it twice as much as you. But I hope not. I hope you do enjoy it, and that it interests you enough to encourage you to find out more about the work of those theorists who in my view offer the best route to understanding people.

Trevor Butt

Huddersfield

November 2002 